\title{
EFEKTIVITAS BERMAIN LEGO DALAM MENINGKATKAN KEMAMPUAN KERJA SAMA PADA KELOMPOK PIAY GROUP
}

\author{
1Rima Rohimah, ${ }^{2}$ Rohmalina \\ ${ }^{1}$ IKIP Siliwangi, Jl. Terusan Jenderal Sudirman, Cimahi \\ 2 IKIP Siliwangi, J1. Terusan Jenderal Sudirman, Cimahi \\ 1rimarohimah24@gmail.com, 2rohmalina@ikipsiliwangi.ac.id
}

\begin{abstract}
This research is backed by a lack of ability to cooperate in children in the play group class, children are more commonly seen using toys used for each person so that the child becomes passive. Therefore, this research aims to improve the ability to cooperate learners by effectively playing Lego game tools in play group. This research uses qualitative methods, in this research the media learning used is Lego, and the source of the technique of collecting this research using observation and documentation, to the conclusion of this research acquired the results that Lego can improve the ability to work together. It can be seen from the emergence of children playing more than 2 people or groups. To make the LEGO arrangements that the child wants to create together, or create ideas as a result of common thought, the desire will work together so that reciprocal satisfaction arises based on the same taste and desire. Cooperation in early childhood is very important in relation to the development of social emotions that will connect children with their environment, friends, and society.
\end{abstract}

Keywords: Lego Games, Teamwork Kkills

\begin{abstract}
ABSTRAK
Penelitian ini dilatar belakangi oleh kurangnya kemampuan kerjasama pada anak di kelas play group, anak lebih sering terlihat menggunakan mainan yang digunakan untuk per orang saja sehingga anak menjadi pasif. Oleh karena itu penelitian ini bertujuan untuk meningkatkan kemampuan kerjasama peserta didik dengan mengefektifkan alat permainan lego di play group. Penelitian ini menggunakan metode kualitatif, dalam penelitian ini media pembelajaran yang digunakan adalah lego, dan teknik pengumpulan sumber penelitian ini menggunakan observasi dan dokumentasi, untuk kesimpulan penelitian ini diperoleh hasil bahwa lego dapat meningkatkan kemampuan bekerja sama. Hal ini dapat dilihat dari munculnya anak bermain lebih dari 2 orang atau kelompok. Untuk membuat pengaturan lego yang ingin anak ciptakan bersama, atau membuat ide sebagai hasil dari pemikiran bersama, maka munculah keinginan bekerja sama sehingga kepuasan timbal balik muncul berdasarkan rasa dan keinginan yang sama. Kerja sama pada anak usia dini sangat penting terkait dengan perkembangan emosi-sosial yang akan menghubungkan anak-anak dengan lingkungan, teman, dan masyarakatnya.
\end{abstract}

Kata Kunci: Permainan Lego, Kemampuan Kerja Sama 


\section{PENDAHULUAN}

Guru merupakan komponen penting sebagai penentu keberhasilan peserta didik dalam kegiatan pembelajaran di kelas. Salah satu peran guru dalam kegiatan pembelajaran adalah sebagai fasilitator. Guru sebagai fasilitator dalam kegiatan pembelajaran harus dapat menciptakan suasana kelas yang kondusif. Adapun yang penting diperhatikan oleh seorang guru yakni, memikirkan dan merencanakan proses pembelajaran yang menarik bagi peserta didik, agar anak semangat dalam belajar dan aktif terlibat dalam proses pembelajaran terutama dalam belajar, sehingga pembelajaran menjadi efektif.

Pembelajaran anak usia dini telah banyak melalui sentra-sentra main dengan menyiapkan berbagai alat permainan memberikan kesempatan kepada anak untuk memilih dan bermain sesuai dengan minat dan kemauannya dan memberikan kebebasan kepada anak untuk beraktifitas sesuai dengan minatnya (Rohmalina, 2016).

Menurut Purnama, dkk (2019:2) bermain merupakan kebutuhan alamiah bagi anak dan memiliki kedudukan yang sangat penting. Banyak manfaat yang bisa diperoleh dari kegiatan bermain, bermain menjadi prioritas utama dalam kegiatan pembelajaran anak usia dini. Selain sebagai aktivitas bersenang-senang, bermain dimaksudkan sebagai sarana belajar anak karena belajar anak memang melalui aktivitas bermain. Melalui bermain, seorang anak dapat belajar berbagai hal baru yang belum ia ketahui sebelumnya. Bermain dapat menstimulasi berbagai perkembangan anak, seperti fisik-motorik, kognitif, logikamatematika, bahasa, moral-agama, sosialemosional, dan seni. Melalui bermain pula, kreativitas anak akan terbangun dan berkembang dengan maksimal.

Ada berbagai cara dalam mengembangkan kemampuan kerja sama, salah satunya dapat dilakukan melalui penerapan pembelajaran dengan kerja kelompok. Kerja kelompok merupakan salah satu strategi belajar mengajar dimana anak dibagi menjadi beberapa kelompok dan bekerja bersama dalam menyelesaikan tugas atau memecahkan masalah tertentu, dan berusaha mencapai tujuan bersama. Pada uraian diatas kerja kelompok yang dilakukan lebih mengacu pada kerjasama saat bermain alat permainan lego.

Secara umum, tujuan bermian dapat diklasifikasikan menjadi beberapa bentuk sebagai berikut : (Purnama dkk 2019:11)
a) Untuk eksplorasi anak
b) Untuk eksperimen anak
c) Untuk imitasi anak
d) Untuk adaptasi ana

Adapun beberapa manfaat bermain tersebut antara lain yaitu Melatih kemampuan motorik, Melatih konsentrasi, Kemampuan sosialisasi meningkat, dan juga mengembangkan kemampuan sosial (Purnama, dkk, 2019:12). 
Dari hasil observasi awal sebelum penelitian, ketika anak-anak sedang bermain pada kelompok play group anak lebih sering terlihat menggunakan mainan yang digunakan untuk perorang saja sehingga anak menjadi pasif.

Adapun Rumusan Masalah pada penelitian ini yakni: bagaimana efektifitas permainan lego dalam meningkatkan kemampuan kerjasama pada anak di kelompok play group?

Berdasarkan rumusan masalah diatas maka tujuan penelitian ini yakni: untuk mengetahu bagaimana efektifitas permainan lego dalam meningkatkan kemampuan kerjasama pada anak di kelompok play group.

\section{METODOLOGI}

Metode yang digunakan adalah metode kualitatif. Menurut Denzin \& Lincoln mengutif (dalam Anggito dan setiawan 2019:6) menyatakan bahwa penelitian kualitatif adalah penelitian yang menggunakan latar belakang dengan maksud menafsirkan fenomena yang terjadi dan dilakukan dengan jalan melibatkan berbagai metode yang ada. dalam buku yang berjudul "metode penelitian kualitatif oleh Anggito dan Setiawan (2019:6) juga Erickson menyatakan bahwa penelitian kualitatif berusaha untuk menemukan atau menggali dan menggambarkan secara naratif kegiatan yang dilakukan dan dampak dari tindakan yang dilakukan terhadap kehidupan mereka.

Dari beberapa pendapat ahli diatas maka dapat disimpulkan bahwa penelitian kualitatif adalah pengumpulan data pada suatu latar alamiah dengan maksud menafsirkan fenomena yang terjadi dimana peneliti adalah sebagai instrument kunci, pengambilan sampel sumber data dilakukan secara purposive dan snowbaal, teknik pengumpulan dengan trianggulasi (gabungan), analisis data bersifat induktif/kualitatif. Dan hasil penelitian kualitatif lebih menekankan makna daripada generalisasi. (Anggito \&Setiawan, 2019:7)

\section{HASIL DAN PEMBAHASAN Hasil}

Pada dasarnya dunia anak adalah dunia bermain, maka metode pembelajaran yang tepat untuk anak adalah belajar sambil bermain, Secara bahasa bermain diartikan sebagai suatu aktivitas yang langsung atau spontan contohnya seperti saat anak bertemu orang lain maka akan terjadilah interaksi, atau bertemu dengan berbagai benda di sekitarnya hal ini dapat memicu rasa senang hati (gembira) atas inisiatif sendiri dengan menggunakan khayal (imajinasi), menggunakan pancaindra, serta seluruh anggota tubuhnya. Bermain juga dapat diartikan sebagai kegiatan yang dilakukan anak untuk menumbuhkan rasa senang dan puas terhadap apapun yang terjadi secara spontan.

Menurut Purnama dkk, (2019:6) Bentuk permainan anak diseluruh dunia dari waktu ke waktu nampak berbedabeda atau lebih variatif, namun esensinya tetaplah sama yakni:
a. Aktif
b. Menyenangkan
c. Motivasi internal
d. Memiliki aturan
e. Simbolis dan berarti 
Adapun permainan yang digunakan dalam penelitian ini adalah lego, dengan tujuan untuk melatih kemampuan kerjasama ketika anak-anak bermain lego bersama teman atau saudaranya, secara tidak langsung, mereka harus berkomunikasi untuk menentukan bentuk apa yang akan mereka buat. Hal ini dapat membantu anak-anak dalam mengemukakan pendapatnya secara percaya diri. Selain itu, mereka akan lebih siap untuk bersosialisasi dengan orang lain di lingkungan sekitarnya.

\section{Pembahasan}

Dari uraian diatas sangat berkaitan dengan hasil analisis yang dilakukan di sekolah Taman Pendidikan Bunda Floria mengenai efektifitas permainan lego terhadap kemampuan kerja sama anak yaitu :

1) Alat permainan lego digunakan untuk bermain dan juga belajar, tergantung tema dan kebutuhannya

2) Setiap ruangan kelas dilengkapi alat permainan lego agar semua anak dapat bermain secara bersam-sama, dan saling bekerja sama

3) Anak dengan lebih leluasa mengeksplore ide kreatifnya saat bermain diluar jam belajar atau ketika jam istirahat

4) Jumlah lego pada setiap kelas dibatasi, agar anak dapat memungkinkan untuk saling berbagi atau dengan bertukar bentuk lego yang dia perlukan dengan temannya

5) Anak secara tidak langsung mulai dapat mengenal tentang perbedaan warna, perbedaan bentuk, dan jumlah lego
6) Anak yang sudah terbiasa bermain lego, menjadi lebih peduli pada temannya, jika temannya memerlukan lego langsung dibantu, atau meminta bantuan maka langsung diberi tahu.

\section{KESIMPULAN}

Simpulan hasil penelitian efektifitas permainan lego dalam meningkatkan kemampuan kerjasama yaitu: Terdapat perbedaan sikap antara anak yang tidak pernah bermain lego dan anak yang suka bermain lego, perbedaan tersebut terlihat saat dilakukan observasi ketika semua anak sedang bermain di jam istirahat, anak yang bermain lego menunjukan sikap kerjasama dan melakukan komunikasi terhadap temannya yang juga ikut bermain lego, maka dapat disimpulkan bahwa efektifitas permainan lego dapat meningkatkan kemampuan kerjasama anak di kelompok playgroup.

Maka permainan Lego dapat meningkatkan kemampuan bekerja sama muncul saat anak bermain lebih dari 2 orang atau kelompok. Untuk membuat pengaturan lego yang ingin Anak ciptakan bersama, atau membuat ide sebagai hasil dari pemikiran bersama, maka muncullah keinginan bekerja sama sehingga kepuasan timbal balik muncul berdasarkan rasa dan keinginan yang sama. Kerja sama pada anak usia dini sangat penting terkait dengan perkembangan emosi sosial yang akan menghubungkan anak-anak dengan lingkungan, teman, dan masyarakatnya

\section{DAFTAR PUSTAKA}

Purnama, S., Hijriyani, Y. H. S., \& Heldanta (2019). Pengembangan Alat Permainan Edukatif Anak Usia 
ISSN : 2614-6347 (Print) 2714-4107 (Online)

Vol.2 | No.5 | September 2019

Dini. Bandung. PT Remaja Sampah Di Paud Siaga Kota Rosdakarya Cimahi”. Tunas Siliwangi. 2 (2), pp.

Monique, S. (2017) Segudang Manfaat B e r m a in L e go ht t p s:// www.ruparupa.com/blog/segudangmanfaat-bermain-lego/

Anggito, A., \& Setiawan, J. (2018). Metodologi Penelitian Kualitatif. Sukabumi. CV Jejak

Rohmalina (2016). "3r"“ (Reduce, Reuse, Recycle) "Sebagai Inovasi Media Pembelajaran Paud Dalam Menyongsong Indonesia Bebas 